\title{
Contemporaneous Traditions: The World in Indigenous Art/ Indigenous Art in the World
}

\author{
Ian McLean
}

It may turn out ... that going back can be a way to go forward. ${ }^{1}$

\section{Multiple Modernities}

In the 1980s postmodernism's retro culture was widely diagnosed as the endgame of modernism. Some suggested that a bigger endgame was in play. Hal Foster glimpsed the end of a ruling civilisation: 'a moment when the West, its limit apparently broached by an all but global capital, has begun to recycle its own historical episodes'. ${ }^{2}$ By the end of the century the West's cultural hegemony did indeed seem over. From about 1990 global capital began delivering a completely deterritorialised contemporary art practice. Even Indigenous art, previously considered a primitive artifact of pre-modern times, was claimed (by a few) for contemporary art. ${ }^{3}$ This is one reason why Terry Smith believes that 'Modernism' and what he names 'Contemporary Art' are 'different in kind'. Yet one thing did not change. Deterritorialised or not, modern, anti-modern, postmodern or contemporary, it is all the culture of capitalism.

Postmodern deterritorialisation coincided with the deterritorialisation of capital spearheaded by economic deregulation i.e., the surrender of nation-state regulation of capital to financial globalisation. ${ }^{5}$ Just as Marx and Engels had predicted in the Communist Manifesto, having used the West to subjugate the rest for the expansion of capital, capitalism now turned on Western nations.

\footnotetext{
1 Berman, M. 1982, All That is Solid Melts into Air: The Experience of Modernity, New York, Simon and Schuster.

2 Foster, H. 1985, “The "Primitive" Unconscious of Modern Art', October, vol. 34, p. 69.

3 McLean, I. 2011, 'How Aborigines Invented the Idea of Contemporary Art', in I. McLean (ed.), How Aborigines Invented the Idea of Contemporary Art: Writings on Aboriginal Art 1980-2006, Brisbane \& Sydney, Institute of Modern Art \& Power Publications.

4 Smith, T. 2011, Contemporary Art: World Currents, London, Laurence King Publishing, p. 9.

5 Jameson, F. 1997, ‘Culture and Finance Capital', Critical Inquiry, vol. 24, no. 1, pp. 246-65.
} 
Or as Slavoj Žižek described it, former colonial relations were globalised, so that today 'there are only colonies, no colonising countries - the colonising power is no longer a Nation-State but directly the global company' ${ }^{6}$

These economic and cultural deterritorialisations were the culmination of postcolonial power arrangements that emerged in the second half of the twentieth century. As capitalism globalised it changed its stripes from a site of antagonistic confrontation (with tradition, communism, the proletariat and the colonised) to the smooth invisible logic of the Real. Now, said Žižek, we face 'the massive presence of capitalism as universal world system', meaning that 'everybody silently accepts that capitalism is here to stay. ${ }^{7}$ It follows, argued Žižek, that 'the ideal form of ideology of this global capitalism is multiculturalism', the attitude which, from a kind of empty global position, treats each local culture the way the coloniser treats colonised people - as "natives" whose mores are to be carefully studied and "respected". That is to say, the relationship between traditional imperialist colonialism and global capitalist self-colonisation is exactly the same as between Western cultural imperialism and multiculturalism' ${ }^{8}$ A similar equation can be drawn between modernism (as the aesthetic expression of imperialist colonialism) and contemporary art (as the aesthetic expression of global capitalism). Whatever their different appearances, each is a theoretical object of capitalism.

One symptom of self-regulated or autonomous global capitalism (i.e., a capitalism no longer in need of the Western nation-state) was the erosion of Western hegemony. Before 1990 it appeared that modernity was the result of forces largely internal to Europe's history and formation'.$^{9}$ Even postmodernism was then considered a Western phenomenon. In the early 1990s Stuart Hall could still confidently assert that the terms 'modern' and 'Western' were 'virtually identical'. ${ }^{10}$ But by the end of the decade this was no longer the case. Charles Taylor bluntly announced in 1999 that 'modernity is not specifically Western'. ${ }^{11}$ Current theories of modernity, argued Taylor, don't account for 'the multiple encounters of non-Western cultures with the exigencies of science, technology, and industrialization.' ${ }^{12}$ 'Instead of speaking of modernity in the singular', he proposed 'we should better speak of "alternative modernities"' ${ }^{13}$

\footnotetext{
6 Žižek, S. 1997, 'Multiculturalism, or, the Cultural Logic of Multinational Capitalism', New Left Review, vol. 1, iss. 234, Sept-Oct, p. 44.

7 Žižek, 'Multiculturalism', p. 46.

8 Ibid., p. 44.

9 Hall, S. 1992, 'The West and the Rest: Discourse and Power', in S. Hall and B. Gieben (eds), The Formations of Modernity: Understanding Modern Societies an Introduction Book 1 (Introduction to Sociology), Cambridge, Polity Press, p. 278.

10 Hall, 'The West and the Rest', p. 277.

11 Taylor, C. 1999, 'Two Theories of Modernity', Public Culture, vol. 11, no. 1, p. 169.

12 Taylor, 'Two Theories of Modernity', p. 160.

13 Ibid., p. 162.
} 
The next year Shmuel Eisenstadt developed similar ideas into a cogent manifesto with the more arresting heading of 'multiple modernities.' ${ }^{14}$ This new narrative of multiple modernities is the master signifier of globalisation, and is rapidly reordering the critical landscape. ${ }^{15}$

The impact of this new master signifier on the art-world is already profound, most obviously in the notion of 'world art' ${ }^{16}$ Further, as well as reshaping the present, master signifiers reshape the past. Now it increasingly seems that modernism was always global, multiple and divided, rather than Western and singularly formalist. 'There are several versions of modernity', said Nicolas Bourriaud at the end of the twentieth century, and it 'cannot be reduced to a rationalist teleology' i.e., formalism. ${ }^{17}$ Far from being 'homogenic and hegemonic', ${ }^{18}$ as it was conventionally thought, 'from its beginnings', wrote Eisenstadt, modernity was 'beset by internal antinomies and structural contradictions' ${ }^{19}$

The new master signifier of multiple modernities also inverts earlier ideas of the West and progress. Now globalism reigns and tradition assumes the reformist role formerly reserved for the modern. This is why late-twentieth-century art is characterised by so many retro styles. Traditions are no longer negated or sublimated, as they were in the modernist myth of progress, but now shape the future. Foster observed:

In 1962 Ricoeur argued that to survive in it [the global culture of modernity] each culture must be grounded in its own indigenous tradition; otherwise this 'civilization' would be domination pure and simple. Similarly, in our own time Jürgen Habermas has argued that the modern West, to restore its identity, must critically appropriate its tradition. ${ }^{20}$

Taylor observed the same strategy in other parts of the world: in wanting 'to avoid the fate of those Aboriginal people who have been engulfed and made over by the external power', non-Western societies are looking for creative adaptations that draw 'on the cultural resources of their tradition' ${ }^{21}$

14 Eisenstadt, S. N. 2000, 'Multiple Modernities', Daedalus, vol. 129, no. 1, pp. 2-29.

15 Fourie, E. 2012, 'A Future for the Theory of Multiple Modernities: Insights From the New Modernization Theory', Social Science Information, vol. 51, no. 1, pp. 52-69.

16 See Belting, H. and Buddensieg, A. (eds), 2009, Global Art: Rewritings, Transformations, and Translations, Ostfildern, Hatje Cantz Verlag; Elkins, J. T. (ed.), 2007, Is Art History Global, London, Routledge; Horst, M. (ed.), 2012, Changing Perspectives: Dealing with Globalisation and the Presentation and Collection of Contemporary Art, Amsterdam, KIT Publishers; Weibel, P. and Buddensieg, A. (eds), 2007, Contemporary Art and the Museum: A Global Perspective, Ostfildern, Hatje Cantz Verlag; and, Zijlmans, K. and van Damme, W. (eds), 2008, World Art Studies: Exploring Concepts and Approaches, Amsterdam, Valiz.

17 Bourriaud, N. 2002, Relational Aesthetics, Paris, Les presses du réel.

18 Eisenstadt, 'Multiple Modernities', p. 13.

19 Ibid., p. 7.

20 Foster, "The "Primitive" Unconscious', p. 69.

21 Taylor, 'Two Theories of Modernity', p. 163. 
However multiculturalism has its limits. The one zone in which the new master signifier of multiple modernities has hardly penetrated is Indigenous cultures, as if its differences are too great to be accommodated. Taylor and Eisenstadt ignore Indigenous cultures in their discussions. The widespread incomprehension of art historians and critics before Indigenous contemporary art remains a feature of art-world discourse. The incomprehension is evident in the most astute critics - such as Foster - as if here the new universal principle of global capitalism is held in suspension in case it disintegrates if applied to Indigenous art. Thus today Indigenous art is what Žižek called a 'symptom' rather than accepted as 'typical' or an example of the 'concrete existence' of the 'Universal' i.e., of global capitalism. ${ }^{22}$

While Indigenous artists working in Western-derived styles have been readily accepted into contemporary art-world discourse - their art meets the condition of global modernity - those working with traditional styles and subjects have not. Nevertheless the latter have had a profound impact on the global contemporary art-world. Foster called this impact the 'ethnographic turn', which he interpreted as a symptom of ethical malaise, diagnosing it as a return of avant-garde primitivism. His cynicism towards the former reflected his scepticism of the latter. Dismissing the 'ethnographic turn' as 'primitivist fantasy', he instead argued for an immanent critique, 'a politics of here and now', without appeal to some transcendent other. 'A strategic sense of complex imbrication', he wrote, 'is more pertinent to our postcolonial situation than a romantic proposal of simple opposition' ${ }^{23}$

Foster was acutely aware that the ethnographic turn is just one of the many 'complicated' and 'compulsive' returns that characterise late twentieth-century art. The critical question today is, he argued, an ethical/political one:

How to tell the difference between a return of an archaic form of art that bolsters conservative tendencies in the present and a return to a lost model of art made in order to displace customary ways of working ? $^{24}$

Foster judged the 'ethnographic turn' an example of the former. Further, he was referring to the Western reception of Indigenous art not Indigenous art itself. The latter remains invisible to his critical eye. When Foster wrote his essay in the early 1990s, Western Desert painting was especially prominent. A type of self-ethnography articulated from a conscious perspective of self-representation and self-determination in the postcolonial world, their art is nothing but a cultural politics of immanence - a point that Foster might have been expected

22 Žižek, 'Multiculturalism', pp. 28-29, 46.

23 Foster, H. 1995, 'The Artist as Ethnographer?', in G. E. Marcus and F. R. Myers (eds), The Traffic in Culture: Refiguring Art and Anthropology, Berkeley, University of California Press, pp. 302-304.

24 Foster, H. 1994, 'What's Neo about the Neo-Avant-Garde', October, vol. 70, Autumn, pp. 5-32. 
to notice. Instead such art remains beyond his critical eye, as if reduced to ethnographic objects. Indeed he was sceptical of their transformation into the category of art — or at least he was in 1985: 'Though presented as art, the tribal objects are manifestly the ruins of (mostly) dead cultures' ${ }^{25}$ In simultaneously placing Indigenous art outside and denying that there is an outside in the global economy, Foster effectively sublimates it twice. Here it is lodged like a virus in Western consciousness. Foster may have identified the ethnographic turn as a symptom, but he poorly diagnosed its pathology.

\section{Inventing Indigenous Modernity}

One consequence of the West's sublimations is that it has never been indifferent to the rest. While Indigenous art was often dismissed as folk or primitive art, the sublimations that produced these judgments also lent Indigenous art the allure of the other. It became an object of desire. Modernism is noted for its restless anxiety about its constructions of otherness. This is particularly evident in the ways that the avant-garde seized upon the potential of the marginalised to desublimate the West's sublimations.

The avant-garde's initial turn to Indigenous art at the turn of the twentieth century followed on the heels of far reaching change in European attitudes to Indigenous cultures caused by the trope of social evolutionism which coincided with the rule of imperialist capitalism. Because social evolutionism held that cultures evolved, primitive cultures were seen to possess the key to the origins of modern ones. In an unexpected reversal, the very opposition that once excluded Indigenous art now privileged it. The virus had taken hold.

This post-Darwinian imbrication of the primitive and the modern in a social ecology - a habitus - provided anthropology with its guiding rationale as an academic discipline and science. From this point Indigenous art fell under the spell of a mysterious force that made it an increasingly seductive but also unmanageable object. Firstly, the methodological demands of the academy resulted in the intensive collection and scientific analysis of Indigenous material culture, stimulating Indigenous production for this new market and an academic interest in the material for its own sake. Soon it began to intrigue connoisseurs and from that point an emergent European modernism became closely bound to the aesthetic qualities of Indigenous art, inaugurating what is conventionally dubbed avant-garde primitivism. It has been a vital ingredient of twentiethcentury modernism and arguably still is. ${ }^{26}$

25 Foster, 'The "Primitive" Unconscious', p. 55.

26 Clifford, J. 1987, 'Of Other Peoples: Beyond the "Salvage" Paradigm', in H. Foster (ed.), Discussions in Contemporary Culture 1, Seattle, Bay Press, pp. 121-129. 
'The history of twentieth-century art', Bernard Smith observed, 'can be written in terms of primitivism.'27 This was unequivocally demonstrated in MoMA's 1984 exhibition, 'Primitivism in 20th Century Art'. The exhibition inadvertently revealed the extent to which European modernism is a form of retro-Indigenous art. This had enormous repercussions. Framed by an emerging postcolonial criticism, the art-world suddenly found itself knee deep in its own excrement, unleashing a torrent of moral accusations about the function of the primitive in modernism and the way in which formalism had repressed the Indigenous voice. ${ }^{28}$ The fallout was profound. The terms 'primitive' and 'tradition' became dirty words, and anti-formalist approaches in art theory and practice took hold, from abject art and the related reappraisal of modernism under the sign of George Bataille and the informal, ${ }^{29}$ to what Foster called the 'ethnographic turn' (discussed earlier). The latter was most spectacularly evident in the groundbreaking 1989 exhibition 'Magicians of the Earth' - 'billed as the world's first global art show ${ }^{30}$ — in which works by contemporary Indigenous and Western artists were juxtaposed. By this time an emboldened few were touting Indigenous art as a contemporary art practice. ${ }^{31}$

Such leaps of translation between Indigenous and Western art far exceeded the initial conceptual opposition between them, producing what one curator aptly called 'a type of "intellectual vertigo"". ${ }^{32}$ However cracks began to appear in the discourse well before the 1980s. An early sign, evident in the mid-twentieth century, was that non-Western art, including Indigenous art, gained a new official status as fine art on the condition that it remains true to its ethnic traditions. This emerging multiculturalism coincided with the growing crisis of imperialist capitalism. It was a small concession as intolerance towards nonWestern art persisted when it looked Western i.e., modern. ${ }^{33}$ That is, Aborigines gained a visibility but only as primitives not moderns. ${ }^{34}$ In many respects the current reception of Indigenous art falls within this multicultural ethos of ethnic difference. Thus while Indigenous contemporary art is very visible in the

27 Smith, B. 2006, 'Creators and Catalysts: The Modernisation of Australian Indigenous Art', Australian Cultural History, vol. 26, pp. 11-25.

28 Foster, 'The "Primitive" Unconscious'.

29 Bois, Y-A. and Krauss, R. 1997, Formless: A User's Guide, New York, Zone Books.

30 Bishop, C. 2012, Artificial Hells: Participatory Art and the Politcs of Spectatorship, London, Verso, p. 194.

31 Michaels, E. 1989, 'Postmodernism, Appropriation and Western Desert Acrylics', in S. Cramer (ed.), Postmodernism: A Consideration of the Appropriation of Aboriginal Imagery Forum Papers, Brisbane, Institute of Modern Art, pp. 26-34.

32 McClusky, P. 2012, 'Ancestral Modern: Australian Aboriginal Art from the Kaplan \& Levi Collection', in Seattle Art Museum (ed.), http://www.seattleartmuseum.org/exhibit/exhibitDetail.asp?eventID=21215 (viewed 28 May 2012).

33 Araeen, R. 1994, 'New Internationalism, or the Multiculturalism of Global Bantustans', in J. Fisher (ed.), Global Visions: Towards a New Internationalism in the Visual Arts, London, Kala Press in association with The Institute of International Visual Arts.

34 Povinelli, E. A. 2001, The Cunning of Recognition: Indigenous Alterities and the Making of Australian Multiculturalism, Durham, Duke University Press. 
Australian contemporary art-world, it generally has been exhibited in separate gallery spaces. ${ }^{35}$ However, European museums of contemporary art, which are not sites of multiculturalism, have found it difficult to accommodate Indigenous art. Tate Modern is making concerted efforts to embrace the notion of multiple modernities in its exhibition programs but is yet to include Indigenous contemporary art, which remains relegated to the British Museum.

The same story continues across the Channel. In October 2012, 'Aux sources de la Peinture Aborigine: Australie Tjukurrtjanu' — an exhibition of early paintings from the Western Desert contemporary art movement-opened at France's premier ethnographic museum, the Musée du Quai Branly, which has become a site of multiculturalism, not its premier museum of modern and contemporary art, the Georges Pompidou Centre. At the time the latter featured an exhibition of the leading French contemporary artist Bertrand Lavier, which included some of his cast nickel-plated bronze replicas of the sort of Indigenous African sculpture popular with the French surrealists. This work, said Michel Gauthier, 'questions the boundary between the fine arts museum and the ethnographic museum.'36

The exhibition at the Quai Branly had the potential to question this boundary in a far more radical sense. Instead it is confirmed, not just because of the site-like the fine art museum, the ethnographic museum incorporates whatever objects it displays into its discourse - but also because the exhibition got caught in an ethnographic trap of its own making. In the first darkened room so-called traditional ethnographic objects were displayed, in contrast to the modern Indigenous paintings hanging on white walls in the other rooms like modern art. Wall text explains that these rare old artifacts show the iconographic sources of the modern acrylic paintings. In this way the old binary opposition between the modern and tradition is reiterated. The opportunity to invert this relationship - in the manner associated with Lavier - was not just missed but denied. If one looked closely the inversion was not difficult to find, as some of these supposedly rare old artifacts were made by artists in the exhibition, and made after their modern acrylic paintings hanging on the white walls. Tradition, as Foster predicted in 1985, was assuming a new agency in the contemporary world. This could have been the exhibition's thesis, but its presentation confused the issue, positioning the contemporaneity of the acrylic paintings as a form of multiculturalism.

\footnotetext{
35 During the writing of this essay, two state art museums - South Australia, and New South Wales integrated their Indigenous and non-Indigenous Australian collections in significant ways. The Art Gallery of Western Australia did this several years earlier.

36 Gauthier, M. 2012, 'Bertrand Lavier since 1969', in Bertrand Lavier since 1969: The Exhibition, Paris, Centre Pompidou, p. 22.
} 
How then might we theorise what Fred Myers aptly characterised as the 'conundrum of tradition' in Indigenous contemporary art? ${ }^{37}$

\section{Neo-Traditionalism}

Postmodern critiques of the master-narratives of modernity have made most commentators wary of the word 'tradition', its apparent essentialism 'conveying a timeless, unchanging past and the evil twin of modernity' ${ }^{38}$ By contrast, the discourse of multiple modernities dispenses with this myth of Western progress and rehabilitates the notion of tradition. Without it modernity would not multiply.

The discursive function of tradition is well accepted, as is the idea that in the colonial era European authorities invented traditions for themselves and also for their colonial subjects. ${ }^{39}$ Further these invented traditions are self-evidently part of the Western discourse of modernity and especially its myth of progress. The myth of progress is actually a myth of Western progress and non-Western decline. The West construes its traditions within a linear progression between past, present and future, thus gaining agency through history. However it denies non-Western cultures this agency of tradition by inventing non-Western traditions in which this 'axis of durée' ${ }^{40}$ — as Alfred Gell aptly dubbed it - is severed.

Thomas Spear, writing on colonial Africa, shows how both sides used traditionalism to 'assert present interests in terms of the past'. It was, he said, 'reinterpreted, reformed and reconstructed by subjects and rulers alike.'41 Arguing for a more complex dialogical agency in which both sides employed discourses of tradition for their own purposes, he concluded that traditionalism was an ambivalent 'perilous process that could both challenge and support colonial hegemony'. ${ }^{42}$

Spear's main point is that tradition is part of what he called 'the ongoing politics of neo-traditionalism' ${ }^{\prime 3}$ that shaped the ideology of colonial cultures. However, while neo-traditionalism is inventive, he cautioned against the belief that

\footnotetext{
37 Myers, F. R. 2004, 'Unsettled Business: Acrylic Painting, Tradition, and Indigenous Being', Visual Anthropology, vol. 17, pp. 247-71.

38 Spear, T. 2003, 'Neo-Traditionalism and the Limits of Invention in British Colonial Africa', The Journal of African History, vol. 44, no. 1, p. 5.

39 Hobsbawm, E. J. and Ranger, T. O. (eds), 1983, The Invention of Tradition, Cambridge, Cambridge University Press.

40 Gell, A. 1998, Art and Agency: An Anthroplogical Theory, Oxford, Clarendon Press, p. 236.

41 Spear, 'Neo-Traditionalism and the Limits', p. 4.

42 Ibid., p. 13.

43 Ibid., p. 4.
} 
traditions are pure inventions. Rather, neo-traditionalism is 'an autonomous and self-regulating process' in which traditions are 'continually renewed'. ${ }^{44}$ That is, the discourse has its own unpredictable agency. Hence:

when colonial authorities sought to appropriate [African] tradition they became subject to a discourse of which they had little knowledge or control. And when they sought to impose their own discourse, such as Christianity or democracy, they risked its appropriation [by the colonised] to challenge their own authority. ${ }^{45}$

Not only are Western and African thinking entangled, so too are the discourses of traditionalism, neo-traditionalism and modernism. Modernity seemingly becomes as much an invention of tradition as tradition is an invention of modernity. Either way, Spear casts the discourse of neo-traditionalism as an ideology of modernity. Indeed, the prefix 'neo' makes it a type of modernism and suggests the retro styles of postmodernism. And like the retro styles of postmodernism, much Indigenous contemporary art has a political agenda designed to leverage power in the postcolonial world. In accord with Spear's analysis, the current discourse on Western Desert painting emphasises its use of traditional designs in new commercialised contexts, ${ }^{46}$ and the art's stylistic affinity with Western modernism ${ }^{47}$ made it seem to some a type of postmodernism. ${ }^{48}$

However, the continuing prohibition of the term 'tradition' confirms its conventional role as a sublimated other and thus an object of desire. Indeed museums can't resist the poetic frisson of its supposedly untranslatable terms. Typical is 'Ancestral Modern' - the name of an exhibition of Aboriginal contemporary art at the Seattle Art Museum in 2012. No wonder Indigenous contemporary art largely waits in the wings while other non-Western contemporary art slowly but surely finds a place in art museums and a discourse once reserved for European modernists as the new face of multicultural cosmopolitan capitalism.

\section{Theorising Indigenous Modernism}

At stake in theorising Indigenous modernism is not the fact of modernity's global reach, which is a given, but the nature of its relations. Take Marshall

44 Ibid., p. 6

45 Ibid., pp. 6-7.

46 Bardon, G. 1979, Aboriginal Art of the Western Desert, Adelaide, Rigby.

47 Baume, N. 1989, 'The Interpretation of Dreamings: The Australian Aboriginal Acrylic Movement', Art \& Text, vol. 33, pp. 110-20.

48 Michaels, 'Postmodernism, Appropriation'. 
Berman's influential All That is Solid Melts into Air (1982). It owes much to New Left critique of the 1960s and 70s, and quickly became a classic of its time. Berman argued that 'modernity can be said to unite all mankind'. Cutting 'across all boundaries of geography and ethnicity, of class and nationality, of religion and ideology', ${ }^{49}$ modernity draws everyone into its orbit. This is, he reasoned, because of its psychological impact. In reaching into the very psyche of individuals, modernity imposes itself on all persons and all walks and aspects of life, from the concrete megapolis to the dusty streets of remote Aboriginal communities. No one escapes what we might (ironically) dub modernity's universal multiculturalism.

Because Berman theorises modernity as primarily a psychological rather than social, political or economic formation, he minimises the significance of its different histories and their different social formations. ${ }^{50}$ His modernity is homogenic and hegemonic, so much that only it, and not the traditions in which it operates, provides 'modern men and women the power to change the world that is changing them' ${ }^{51}$ In such theorisations, as Taylor observed: 'The march of modernity will end up making all cultures look the same. This means of course, that we expect they will end up looking Western. ${ }^{52}$ In other words, wherever it appears modernity is, to use a neo-Darwinian metaphor, the replication of a singular genotype. While this might explain how Indigenous cultures were modernised, the explanation is not a theory of Indigenous modernity as it denies that there is anything Indigenous about it.

If Berman understands modernity as a genotype, an information set, the theory of multiple modernities argues that it is expressed in highly plastic phenotypes, each shaped by its habitus. According to Taylor and Eisenstadt there are many different expressions of modernity because there are many different traditions and social environments in which they form. Here modernity is not an ideal that replicates particular versions of itself. A more apt metaphor is Jameson's suggestion that capitalism is like a virus. ${ }^{53}$ It implies that modernity infects various bodies or traditions that in turn produce their own distinctive antibodies. Subject to a type of adaptive immune response by the infected culture or tradition, the virus of modernity is thus reshaped into a compatible form. These counter-modernities are, in effect, highly plastic types of modernities.

If imagined as a virus, modernity is an information set (distinguished by rationalised or self-ordering processes) that originated in Europe - or maybe

49 Berman, M. 1982, All That is Solid Melts into Air: The Experience of Modernity, New York, Simon and Schuster, p. 15.

50 Anderson, P. 1984, 'Modernity and Revolution', New Left Review, vol. 1, no. 144, pp. 96-113.

51 Berman, M. 1984, 'The Signs in the Street: A Response to Perry Anderson', New Left Review, vol. 2, no.

144, pp. 115-6.

52 Taylor, C. 1999, 'Two Theories of Modernity', Public Culture, vol. 11, no. 1, p. 161.

53 Jameson, 'Culture and Finance Capital', p. 249. 
in its interactions with other cultures - but with a global vector that harnesses the reproductive machinery of host cultures in a systemic and transforming fashion.

The variability of traditions means that modernity has had different consequences for different people at different times. Certainly its relations of power have never been equal, and whatever the common thread of its narratives, its outcomes have been manifold. Modernisation has been experienced as a narrative of liberation but also one of destruction and despair. Nevertheless Indigenous Australians have, like all other peoples of the world, made from the modernity infecting them specific local modernities of their own. And they have been making these local modernities since the beginning of the colonising process. There are long histories of Indigenous modernisms and they are global in scope.

\section{A Global History of Indigenous Modernity}

Jameson observed that shifts in capitalism over the centuries lack any teleology or design. They are, he said, characterised by unpredictable dialectical reversals, 'whereby winners lose and losers sometimes win' ${ }^{54}$ Comparing their workings to 'a kind of virus', he argued that their 'development is something like an epidemic' or 'fire' that burns itself out or leaps 'to new and more propitious settings, in which the preconditions are favorable to renewed development ${ }^{\prime} .{ }^{55}$

This is evident if we analyze the cultural impact of globalisation and its role in the formation of Indigenous modernity. When Goethe first broached the idea of a 'world literature' in the early nineteenth century, his thinking reflected the Enlightenment's universalising discourse and the impact on him of non-Western literature and contemporary voyages of discovery in which enlightenment was sought not in the grand tour of Italian monuments and classical ruins, but a much grander scientific tour of the world. ${ }^{56}$ When in the mid-nineteenth century Marx took up Goethe's idea he reconfigured a similar habitus into quite a different image, namely the imperialism of world empires, predicting that because 'the bourgeoisie has through its exploitation of the world market given a cosmopolitan character to production and consumption in every country', 'national one-sidedness and narrow-mindedness become more and more impossible, and from the numerous national and local literatures, there arises a 
world literature. ${ }^{57}$ Yet within a century of Marx writing this the world empires had collapsed and nation states were the principal habitus of modernity and the main agent of globalisation.

In the age of world empires modernity was a triumphal European procession before which other nations could only kneel and Indigenous ones succumb. By contrast, with the emergence of the nation state and its discourse of modernism, Indigenous art entered into a new relationship with the state, acquiring a status disproportionate to its peripheral power. This is because Indigenous art added something vital to the centre. In Europe it was an essential ingredient of Cubism and Surrealism. In Australia Indigenous culture remains a central ingredient in the emerging nation state's articulation of a national identity. This was also often the case in other former colonies as each sought to consolidate its rule as an independent postcolonial nation state. How can we understand this development? What occurred in the movement from the modernity of world empires to that of the nation state that catapulted Indigenous art from oblivion to fetish?

Firstly, when in the second half of the nineteenth century European modernists sought to re-invent their neo-classical inheritance in the heroism of the streets, they were generally disappointed to discover a troubling lack. ${ }^{58}$ By the turn of the twentieth century Indigenous art was becoming a substitute for this lack, providing the model for a resistant modernism. One nostalgia, and with it one universal, was traded for another. Indigenous aesthetic values - as European modernists perceived them-displaced neo-classicism as the ideal, providing twentieth-century modernism with its characteristic style. By the inter-war years Indigenous art had assumed the figure of the universal.

Secondly, the pervasive power of the nation state brought Indigenous cultures into a new alliance with modernity and capitalist relations. Tim Rowse points out that the Australian nation state replaced policies of coercion and protection that characterised the rule of empire (or capitalist imperialism) with ones that regulated Aboriginal livelihood at a micro level. Rowse had in mind Foucault's notion of modern power, which rather than rule through the sovereign's naked authority, infiltrates the daily routines of its citizens by distributing power in a measured way around the putative norms of modernity and capitalism. This moment of transition, says Rowse, was more or less in place by the 1940s. ${ }^{59}$

57 Marx, K. and Engels, F. 1969, 'Manifesto of the Communist Party', in Marx/Engels Selected Works, Moscow, Progress Publishers, pp. 98-137.

58 Baudelaire, C. 1995, The Painter of Modern Life and Other Essays, trans. Jonathan Mayne, London, Phaidon.

59 Rowse, T. 1998, White Flour, White Power, Cambridge, Cambridge University Press, pp. 7-8. 
Through its assimilation processes the nation state both demanded far more from and promised far more to Indigenous populations than the world empires ever did. Assimilation is not a one-way process in which a more powerful centre simply incorporates a weaker periphery. Rather it also provides new opportunities for Indigenous people to make from modernity and capitalism something of their own. Indeed, distinguishing the modernity of the nation state from that of world empires is the extent to which local Indigenous art shaped the identity discourses of the state, thus providing an opening for Indigenous artists to become modernists. By the mid-twentieth century a few Indigenous artists such as the Australian Albert Namatjira (1902-59) and the American George Morrison (1919-2000) were successfully working within the arena of nation state modernism.

Understanding Morrison's art as a type of modernism is relatively easy. Born and raised on the Chippewa Grand Portage Indian reservation, Morrison studied at the Minnesota School of Art and, after winning a travelling scholarship, at the Art Students League in New York from 1943-46. In 1952 a Fulbright scholarship financed his study in Paris. Part of the Abstract Expressionist group in New York, for most of his career he had teaching positions at various art schools and universities.

Namatjira's career was very different, but understanding his art as a type of modernism is also relatively easy. Born and raised on the Finke River mission in remote central Australia, in 1936 he began painting with the regional modernist Rex Battarbee. Battarbee was part of the national landscape school of painting, which played a central role in developing a distinctive Australian national identity in the years after World War I. Namatjira quickly developed a strong following. He is, with Hans Heysen, the most admired practitioner of this national landscape school.

At the time Namatjira and Morrison were considered modernist artists of Indigenous descent but not makers of Indigenous art. Then Indigenous art was highly visible and popular in Australia and the USA, but as a form of ethnic art, not as a form of modernism. By trading the ethnicity of their art for Western cosmopolitanism, the critical reception of their art preserved the myths of the West and progress that regulated the twentieth-century understanding of modernity. However, the exchange was never neat or transparent, either with artists, the critics or the public. Neither artist, Namatjira especially, fully escaped the hand of multiculturalism.

The colonised generally won their freedoms through forming their own nation states. The exception is Indigenous groups. Denied a place in a world ruled by nation states, recognition of Indigenous autonomy and rights as modern subjects has been late in coming and primarily occurred under the sign of 
globalisation, post-nationalism and postmodernity. ${ }^{60}$ This transitional period is shaping a new meta-narrative of world art that comprises multiple currents of art practice - including Indigenous ones - that are challenging the discourses of multiculturalism. ${ }^{61}$ Whether this is a new epidemic or, as Jameson suggests, the final deterritorialisation of the modernity of the nation state, ${ }^{62}$ it has given Indigenous cultures a new visibility in the world as contemporary art. One sign of this new visibility and shifting power of Indigenous cultures is the adoption of the Declaration on the Rights of Indigenous People in 2007 by the United Nations (UN). The Declaration primarily sought to clarify the rights of Indigenous people in relation to those of the nation state. At stake are contested territories, contested world views and different experiences of modernity.

In 2007 the UN estimated that there were 370 million Indigenous inhabitants of the world (though a fraction of the world's population between them they speak the majority of the 7000 odd languages spoken in the world today). Their territories are found in every continent, but there are no Indigenous nation states. Indigenous nations and territories are ruled by nation states that have been the main vectors of modernity and agents of Indigenous disenfranchisement. Indigenous nations are within and sometimes across several nation states. Thus for them modernity has not been experienced simply in terms of citizenship and national identity. At first denied participation in its processes, when they did finally win citizenship rights they refused to surrender their ancestral identities, which is the usual Faustian bargain of citizenship. Instead many Indigenous people sought to negotiate a path between the modernity of the nation state and their ancestral identities - identities that are simultaneously traditional and contemporary - a vernacular cosmopolitanism. Such art is exemplary of what Spear called 'neo-traditionalism' - a discourse that in asserting present interests in terms of 'an axis of durée' establishes itself within a history, within a continuity between past, present and future 'from which', as Gell says, an 'artist's personhood and agency can be abducted'. ${ }^{63}$ Neo-traditionalism is a means of countering the myth of Western progress that denied Indigenous agency. Seizing the past for the present has as its prize the future and ultimately identity and power, but it remains to be seen if this Indigenous strategy, which on the face of it seems to play into the hand of multiculturalism, can in fact go beyond it.

60 See, Appadurai, A. 1996, Modernity at Large: Cultural Dimensions of Globalisation, Minneapolis, University of Minnesota Press; Bhabha, H. 1990, 'Narrating the Nation', in H. Bhabha (ed.), Nation and Narration, New York, Routledge, pp. 1-7; and, Bhabha, H. 1994, The Location of Culture, New York, Routledge.

61 Smith, 'Currents Of World-Making'.

62 Jameson, 'Culture and Finance Capital'.

63 Gell, Art and Agency. 